\title{
Nationalism and Hungarian Education Policy: Are the Literary Works of Cécile Tormay, József Nyirő, and Albert Wass Appropriate for the Hungarian School Curriculum?
}

\section{Ágnes Huszár}

\begin{abstract}
Recently there have been attempts in Hungary to rehabilitate authors with nationalist, anti-Semitic, and national socialist views and integrate them into Hungarian literary canon, including the suggestion that the works of Cécile Tormay, József Nyirö, and Albert Wass become compulsory school literature. Since one of the most important goals of Hungarian literary education is to reinforce a sense of Hungarian nationalism, the focus is primarily on the authors rather than their literary works and they tend to be presented as role models to students. This paper aims to show that, given that the three authors mentioned above have publicly participated in anti-Semitic and pro-Nazi activities, it would be unethical to place them in a position where they may be lauded as role models for children. It is also argued that only a small part of the literary work of these three authors can be considered aesthetically valuable while all of them had written works containing anti-Semitic and faux-historical elements. Both the authors' choice of topic and their literary style makes them unsuitable as compulsory school literature for children.
\end{abstract}

Keywords: Education Policy, School Curriculum, Hungarian Nationalism, Anti-Semitism, Cécile Tormay, József Nyirö, Albert Wass

Biography: Ágnes Huszár is a linguist and teaches language and gender and sociolinguistics at the graduate level at the University of Pécs and at Eötvös Loránd University. Her recent book-length publications include Bevezetés a gendernyelvészetbe ['Introduction to Language and Gender'] (Tinta Könyvkiadó 2009) and her volume of papers titled A nö terei ['Women's Spaces'] (L'Harmattan 2011).

Although generally the Hungarian public is unconcerned about the authors and literary works chosen as compulsory school literature for students between the ages ten and eighteen, recent suggestions by policy makers regarding Hungarian education policy have given rise to public discussion of the Hungarian school curriculum in general, and of the works of Cécile Tormay, József Nyirö, and Albert Wass in particular. The close relationship between current Hungarian politics and education policy is evidenced by the fact that almost immediately after the reburial of József Nyirő on May 27, 2012 in Székelyudvarhely [Odorheiu Secuiesc], Romania, a decision was made to incorporate his works as well as those of Cécile Tormay and 
Huszár, Ágnes. "Nationalism and Hungarian Education Policy: Are the Literary Works of Cécile Tormay, József Nyirö, and Albert Wass Appropriate for the Hungarian School Curriculum?" Hungarian Cultural Studies. e-Journal of the American Hungarian Educators Association, Volume 7 (2014): http://ahea.pitt.edu

DOI:10.5195/ahea.2014.140

Albert Wass into the Hungarian National Curriculum [Nemzeti Alaptanterv]. The Hungarian National Curriculum is a central document that determines the content of school course materials as well as the skills and competencies that must be taught in public education from grades one through twelve. Schools operate based partially on a local curriculum, but there may be no more than a ten percent deviation of content from the Hungarian National Curriculum, due to the fact that high school education concludes with a centrally devised maturity or secondary school leave taking exam.

One of the arguments in favor of incorporating Cécile Tormay, József Nyirö, and Albert Wass into the Hungarian school curriculum was that the twentieth century Hungarian literary canon only included works from Hungarian authors who were connected either to the Hungarian literary journal Nyugat [West] or those connected with its intellectual heritage, while nationalist "patriotic" authors were left out of the Hungarian literary canon and public education.

Nevertheless, it is generally agreed by literary scholars that in contrast to the nineteenth century, the majority of aesthetically valuable Hungarian literary works from the twentieth century were produced by Western-oriented authors. In the nineteenth century, the most prominent literary trend in Hungary was Hungarian national romanticism, which drew inspiration from the repertoires of Hungarian folk poetry and its most characteristic themes invoked the great historical persons and events of Hungarian history. Two of the most prominent authors of the period, Sándor Petőfi, and János Arany, both belonged to the school of Hungarian national romanticism, which also created a huge market and readership for bourgeois literature. However, by the beginning of the twentieth century, writers such as Kálmán Lisznyay, Károly Szász, and László Szelestey had reduced the literary trend of Hungarian national romanticism to the mere imitation of their talented predecessor and the trend soon fell into decline. Consequently, talented young writers began to turn towards Western-European literary trends such as impressionism or symbolism, but the literature inspired by the Western-European canon turned out to be less palatable and less "Hungarian" to the average Hungarian reader than it was to Hungarian writers. As a result, in the 1920s and 1930s an opposition developed in Hungarian literary circles between the so-called folk and urban writers. Folk writers were concerned with themes of the everyday life of the Hungarian peasantry or the everyday life of nobles in the Hungarian countryside, and the structure and style of their works were reminiscent of nineteenth century Hungarian national romanticism. In contrast, urban writers such as Mihály Babits, Dezső Kosztolányi, and Árpád Tóth showed greater interest in contemporary foreign literature as evidenced by the large body of literary translations produced by these authors as a byproduct of their intellectual pursuits.

After World War II, Hungarian socialist cultural policy reviewed the previously established literary canon and deemed nineteenth century national romanticism an important literary tradition, but with the exception of Gyula Illyés, Pál Szabó, and Péter Veres, the folk writers of the first half of the twentieth century were banished from the Hungarian literary canon and from the education system as "nationalists." However, since the system change after the collapse of the socialist dictatorship in 1989, there have been attempts to change Hungarian literary education by Christian conservative intellectual groups, primarily those affiliated with the right wing democratic party FIDESZ and the Christian Democratic People's Party ['KDNP, Keresztény Demokrata Néppárt'], who opposed the socialist-liberal orientation of the previous regime and demanded that the Hungarian literary curriculum include authors who approach 
Huszár, Ágnes. "Nationalism and Hungarian Education Policy: Are the Literary Works of Cécile Tormay, József Nyirö, and Albert Wass Appropriate for the Hungarian School Curriculum?" Hungarian Cultural Studies. e-Journal of the American Hungarian Educators Association, Volume 7 (2014): http://ahea.pitt.edu

DOI:10.5195/ahea.2014.140

crucial national issues with "true patriotism" (MTI 2012). Such tendencies reminiscent of the opposition between folk and urban writers of the twenties and thirties are especially prevalent in Hungarian politics today, which means that some literary works currently introduced into Hungarian public education can be judged to be admitted based on the authors' political and ideological affiliation rather than their aesthetical value.

Unfortunately, it is no coincidence that the Hungarian national curriculum today is largely influenced by the political affiliation of the authors included therein. Hungarian literary education has in fact historically never been text- or reader-oriented under any political regime, since it has always been primarily concerned with fostering a sense of Hungarian nationalism. Thus the emphasis has been to instill a "correct" interpretation of Hungarian history and literature rather than educating students to become conscious and interpretative readers. Consequently, children between the ages ten and fourteen are still forced to read the works of authors like Mór Jókai or Géza Gárdonyi, barely intelligible archaic novels written over a hundred years ago. These works were made compulsory by Hungarian education policy because the texts inspire patriotism on account of their characters' struggle against the Turkish invaders and the Habsburg empire. Although there had been attempts in the eighties by prominent representatives of Hungarian literary studies such as Iván Horváth and András Veres to compose text-oriented literature course books focusing on textual interpretation within history-oriented literary education, such modernizing educational attempts were met with strong criticism from the public and even from teachers. Similarly, there were attempts at compiling experimental course materials that teachers could volunteer to introduce in their individual classes with the permission of the school principal, but such materials have also never become a part of mainstream education. Consequently, Hungarian literary education continues to devote greater attention to the biography of authors than to their works and presents them as role models despite the pleas of pedagogical experts to abandon this pervasive trend in Hungarian literary education (Gombár 2009). Such a non-literary orientation to the teaching of literature becomes even more problematic when authors such as Cécile Tormay, József Nyirö, and Albert Wass are to join the ranks of authors taught in the Hungarian national curriculum. In the following sections, I shall discuss these three authors in chronological order of their life work and discuss why I deem their literary work to be unsuitable as compulsory school literature.

\section{Cécile Tormay (1875-1937)}

Known as the nemzet irodalmi nagyasszonya ['Great Lady of Hungarian Literature'],

Tormay is an author whose own life and character were considerably more interesting and exciting than the plots and characters of her novels, even though she did draw much of her inspiration from the history of her illustrious family. For instance, both Tormay's maternal and paternal ancestors were ethnic Germans; her maternal great-grandfather, József Spiegel (Tüköry) was an engineer who worked with István Széchenyi during the construction of the Chain Bridge of Budapest, while her paternal grandfather, Károly Krenmüller (Tormay) was an army major during the Hungarian Revolution of 1848 and her father was a state secretary as well as a member of the Hungarian Academy of Sciences. As their Hungarianized names imply, these men of German background turned into ardent Hungarian patriots and proud nobles within the span of a century, their history well traceable in Tormay's family novel A régi házban ['In the Old House'] that narrates the lives of three generations. In fact, just as her German ancestors had 
Huszár, Ágnes. "Nationalism and Hungarian Education Policy: Are the Literary Works of Cécile Tormay, József Nyirö, and Albert Wass Appropriate for the Hungarian School Curriculum?" Hungarian Cultural Studies. e-Journal of the American Hungarian Educators Association, Volume 7 (2014): http://ahea.pitt.edu

DOI:10.5195/ahea.2014.140

turned towards Hungarian nationalism, Cécile Tormay also dedicated her life work to Hungarianness as the most important cultural and "racial" value.

From 1923 until her death in 1937, Tormay was the editor of the Hungarian literary journal Napkelet ['Sunrise,' a play on words since kelet primarily means 'East'], which was established with the purpose of becoming the intellectual opposite of the influential literary journal Nyugat ['West'] published since 1908. As the name of the latter implies, Nyugat primarily represented a Western-European orientation in the face of second-rate imitations of the former great writers of Hungarian national romanticism. In contrast, the play on words in the name Napkelet implies that the rival journal sought to rediscover the Eastern roots of Hungarianness. Due to the journal's influence, Cécile Tormay played an important role in Hungarian literary life between the two world wars as editor, organizer, and a person with literary influence, roles that she fulfilled tactfully and helpfully according to her contemporaries.

Tormay was well-known in Hungarian circles not only as an author and editor, but also as the founder and one of the leaders of the National Association of Hungarian Women (MANSZ Magyar Asszonyok Nemzeti Szövetsége), an association established for conservative women in January 1919. By 1937 it had become a large and influential organization boasting a membership of 500,000. One of the most important tasks of the association was to create foreign language brochures in order to "educate" the West about the "Hungarian issue," which in the association's view concerned the territorial interests of the Hungary "mutilated" by the Treaty of Trianon. In addition, the National Association of Hungarian Women also engaged in charity work, social and child protection activities as well as organizing the vocational training of rural women. Although the association was involved in social issues on behalf of women, it remained strictly conservative regarding crucial issues such as extending women's right to vote. Suffrage had been granted in 1918 to literate women over the age of twenty-four but then limited in amendments and modifications in consequent years. In spite of the social work it did on behalf of women, the National Association of Hungarian Women rejected the 1929 motion to extend active voting rights to women and settled for a limited "passive" vote instead (Kádár 2003).

In 1930, Cécile Tormay received the Corvin Chain award for her work as a writer, journal editor, and public figure. The prize was one of the most prestigious Hungarian awards of the time and had been established for the most illustrious representatives of Hungarian science, literature and art by Governor Miklós Horthy. In Horthy's time, this honor was bestowed on no more than twelve individuals, among whom public figures of the Hungarian aristocracy such as geography scholar Count Pál Teleki, Minister of Religion and Education Count Kúnó Klebelsberg, Calvinist bishop László Ravasz, and Catholic prince-primate Juszticián Serédi. Tormay was well-known not only in Hungary but also abroad: she had been granted Marie Curie's seat upon Curie's death in the International Committee on Intellectual Cooperation, and her literary works had been lauded and translated into several languages. In 1936, she was nominated for the Nobel Prize by a committee that included prominent conservative literary historians János Horváth and János Hankiss, all of whom were also contributors to the journal Napkelet. As such, they were biased in Tormay's favor; in fact, János Hankiss wrote two laudatory biographies of her, one published in 1928 and the other published two years after Tormay's death in 1939. Tormay's nomination was also supported by Jenö Pintér, a lesser known literary historian, and even signed by Károly Pap, a talented Jewish writer who died in Bergen-Belsen in 1945 and actually belonged to the 
Huszár, Ágnes. "Nationalism and Hungarian Education Policy: Are the Literary Works of Cécile Tormay, József Nyirö, and Albert Wass Appropriate for the Hungarian School Curriculum?" Hungarian Cultural Studies. e-Journal of the American Hungarian Educators Association, Volume 7 (2014): http://ahea.pitt.edu

DOI:10.5195/ahea.2014.140

authors of Nyugat. However, the Nobel Prize committee concluded that Tormay's life work was unworthy of the Nobel Prize (Kádár 2003: 11).

In her novels, Tormay glorified the conservative lifestyle of traditional Hungarian nobles, even though this stood in stark contrast with her own lifestyle. She was presumed to have had several lesbian relationships, including an affair with Countess Eduardina Pallavicini that was revealed to the public in 1925 by the countess' husband, Count Rafael Zichy, who declared in front of numerous witnesses that his primary reason for divorce was his wife's affair with Tormay. The affair was discussed in great detail by the Hungarian leftist press. However, the countess and Tormay sued Count Zichy for defamation and won the lawsuit with the help of Miklós Horthy, who personally exerted pressure on the judges to sentence Count Zichy to an eighteen-month prison sentence. Tormay was thus acquitted from Zichy's charges and spent the last decade of her life in Mátraház, where she lived together with her co-editor, Mrs. Lajos Ambrózy-Migazzi, in a villa under their joint ownership.

In spite of her living arrangement with Mrs. Lajos Ambrózy-Migazzi, Tormay denied all charges of lesbianism and such experiences are absent from her literary work as well, most likely due to the contemporary conservative Hungarian milieu. Although some major Western cities were fairly liberal - as evidenced by flourishing lesbian subcultures in cities such as Berlin, or the acceptance of well-known lesbian public persons such as the masculine Marguerite Radclyffe-Hall (1880-1943) who wrote the coming out novel Well of Loneliness (1928), one of the important works of lesbian subculture, or the Swedish writer and lesbian icon Annemarie Schwarzenbach - elsewhere, including in Hungary, worldviews and tastes were extremely conservative. To openly embrace lesbianism would have resulted in complete isolation from society, which was one of the reasons lesbian public figures such as writer and journalist Sarolta Vay opted for a masculine lifestyle in terms of fashion and behavior. Vay's environment tolerated the arrangement and found it more acceptable than an openly lesbian lifestyle, because as Anna Borgos argues, "Vay's cross-dressing and gender-bending seemed to be only way [sic] to avoid the lot of a dependent woman and also the only conceivable way to be lesbian in that age, a strategy and a constraint at the same time" (Borgos 2011: 220).

Considering the fact that Hungarian women could generally earn respect only as wives and mothers during the Horthy era, it is remarkable that Cécile Tormay managed to garner widespread recognition and appreciation as a single woman living in lesbian relationships. For example, upon the early death of her father, Tormay managed to receive the title of "Lady" as bestowed by the Habsburg Emperor and Hungarian King, Ferenc József. This honor also granted her a small pension, one that Tormay and her widowed mother were in great need of as the family had lost its fortune after the Hungarian Revolution of 1848-1849. As a Lady, Tormay had to be addressed as "Madam," which was otherwise only used for married women. The use of such a title completed her already perfect disguise as a conservatively dressed and attractive blonde woman whose image stood in stark contrast to the idea Hungarian contemporaries held of "depraved" lesbians.

Tormay's work was never really evaluated from a literary perspective. Her work primarily received positive reviews during her lifetime due to her great prestige and influence as a writer, editor, and public figure. Under socialism she became persona non grata and was labeled as a pro-Horthy regime writer whose literary works had little to no aesthetic value (Béládi 1966). Only recently have there been a few objective studies of her public activities and 
Huszár, Ágnes. "Nationalism and Hungarian Education Policy: Are the Literary Works of Cécile Tormay, József Nyirö, and Albert Wass Appropriate for the Hungarian School Curriculum?" Hungarian Cultural Studies. e-Journal of the American Hungarian Educators Association, Volume 7 (2014): http://ahea.pitt.edu

DOI:10.5195/ahea.2014.140

literary work, such as Judit Kádár's essay in Kritika (2003). At the same time there have also appeared non-scholarly articles that welcomed the rediscovery of Tormay's work by dismissing proven biographical facts of her life as lies and attempting to discredit Tormay's critics as Marxists (Pirint 2006).

Due to both the themes and the style of Tormay's novels, her literary works are rather removed from today's readers as they usually revolve around the tragic love between people of conflicting temperaments and cultures. For instance, her first novel published in 1911, Emberek a kövek között ['People Among the Rocks'], was written in an impressionistic style bordering on kitsch that tells the mystical love story of a female goat herder and a boy from the plains, where the woman was an unstoppable creature of instinct. She is described as having "the wild storms of the mountains rage in her eyes" [szemében a hegyek vad vihara tombol]; the man is described as having the "great, unbeatable silence of the plains on his lips" [ajkán a puszták nagy, verhetetlen nyugalma]. Regardless, certain scholars have argued that it was precisely these gilded descriptions in People Among the Rocks that made Tormay "one of the best belletrists of the twentieth century" (Grendel 2010: 123).

In Tormay's historical novels such as A fehér barát ['The White Friar'] (1937), the backdrop of the tragic love story is the conflict between Christians and pagans. A fehér barát is part of the trilogy Az ösi küldött ['The Ancient Messenger'] set in the thirteenth century and unfinished at her death. In the trilogy, Ung the protagonist returns to Hungary from Paris just as the country is invaded and occupied by the Tatars. The King of Hungary flees abroad from the unstoppable barbarians, who have also captured Ung's fiancée, Kinga. By the end of the novel, Ung has lost his faith in both Western civilization and in Christianity and goes to the East to find the ancient homeland of the Hungarians and the god of his ancestors. This implies that by converting to Christianity, Hungarians became vulnerable because they lost their ancient strength. At the time of its writing, the public had great expectations for the upcoming volumes, though it is probable that few actually read them due to their tiresome archaic style, complicated plot, and no characters the reader could identify with.

No change in the evaluation of Tormay's work took place in the years following her death in 1937 until the Communist government took control. During that regime, her work was largely dismissed by Hungarian Socialist cultural and education policy. After the fall of socialism, a few of her novels were reprinted in 1990, and though today Tormay's readership is relatively small and most of her literary works received little to no publicity, current Hungarian cultural policy has artificially inflated the appreciation of her works into a Tormay hype. For instance, she was awarded the Hungarian Heritage Award in 2012, which was established in 1995 by the For Hungary Foundation and almost exclusively bestowed on conservative nationalist artists.

Following the resurgence of Tormay's nationalist literary works in the 1990s, her novel $A$ régi ház ['The Old House'] was selected to become the first volume of the National Library, a project funded by the Hungarian government to establish the "literary canon of Hungarian nationalism." The novel is a thinly veiled and idealized history of Tormay's family and relates the history of a German bourgeois family who eventually become ardent Hungarian patriots as they assimilate into Hungarian society. In nineteenth-century Eastern Europe, the ranks of the national bourgeoisie were often filled with a great number of foreign families who gradually integrated both culturally and linguistically into society, and Tormay's novel is considered but 
Huszár, Ágnes. "Nationalism and Hungarian Education Policy: Are the Literary Works of Cécile Tormay, József Nyirö, and Albert Wass Appropriate for the Hungarian School Curriculum?" Hungarian Cultural Studies. e-Journal of the American Hungarian Educators Association, Volume 7 (2014): http://ahea.pitt.edu

DOI:10.5195/ahea.2014.140

one of the many similar family novels emerging at this time, along with Roger Martin du Gard's Les Thibaults ['The Thibaults'] (1922-1940) and Mihály Babits' novel Halálfiai ['Destined to Die'] (1927) (Jankovics 1986). The plot revolves around the financial and moral dilapidation of the German family because these sympathetic characters are too magnanimous and unassuming in a corrupt and ruthless environment of Jewish bankers, who cheat and rob the family of their ancestral fortune. In the novel, the third generation of the family bears only one son, the weak and easily manipulated Kristóf, who has no affinity for studies or work and does nothing but spend his father's and grandfather's hard-earned fortune. He invests the family fortune into dubious companies at the suggestion of stock exchange agents and as a consequence loses his own and even his sister's money. When he realizes his bankruptcy, the following scene unfolds in front of him:

...strange faces swept past him mere inches from his face. The air was filled with the nauseating stench of their sweat. Kristóf's gaze became rigid and glassy. Faces... faces of unfamiliar races. Some of them flashed pale smiles. These had won. Everything will be theirs. It's only a matter of time. They will have the gold, the city, the country (Tormay n. d.:164).

[...egészen közel az arcához idegen arcok húzódtak el elötte. A levegöben émelyitö izzadtságszag mozgott velük. Kristóf tekintete merev és üveges lett. Arcok... idegen fajú arcok. Néhányan sápadtan mosolyogtak. Ezek nyertek. Övék lesz minden. Csak idö kérdése. Övék lesz az arany, a város, az ország.]

Tormay's novel A régi ház may read like a faint and difficult imitation of Thomas Mann's Buddenbrooks, but it is a prime example of Tormay's extreme anti-Semitism. This also forms the basis of her most well-known book, the diary novel Bujdosó könyv ['The Hiding Book'] (1920-1921), which reads like a manual of extreme right wing ideology. The story of Bujdosó könyv begins in the days of the Aster Revolution in October 1918 and ends in late summer of 1919, when the author who fled from Budapest and had been hiding under an alias in the country, finally manages to return to her mother. The novel uses a diary-like format to recount the events of 1918 and 1919, from the murder of István Tisza and the declaration of the Hungarian Soviet Republic to the rise and fall of the Communist regime, and condemns the Jewish population as the most savage enemy of Hungarians for allowing communism to spread to Hungary from Russia. In her text, Tormay uses the dehumanizing tropes of anti-Semitism to present the Jewish population as gomba, penész, vértetü ['fungi, blight, and parasites'] infesting the ancient tree of Hungary, and who acted as advisors and accomplices of the dimwitted Mihály Károlyi to spark the Aster Revolution. Tormay views Jewish people as egy démoni ellenség ['a demonic enemy'] that triumphed and rose to power with the Hungarian Soviet Republic, in which the only goal of the hájas béka ['fat toad'] Béla Kun and the fekete hiénaember ['black hyena man'] Tibor Samuely was to destroy Hungarians and enslave the entire Carpathian Basin. The entirety of Tormay's fictive Bujdosó könyv is a condemnation of "bad-looking people, suspicious vagabonds, drunken sailors and caftan-clad Galician Jews" [rossz külsejü emberek, gyanús csavargók, részeg matrózok, kaftános galíciai zsidók] (vol. 1, 93), but Tormay also claimed that her novel was a factual recounting of events and her claim was accepted by many 
Huszár, Ágnes. "Nationalism and Hungarian Education Policy: Are the Literary Works of Cécile Tormay, József Nyirö, and Albert Wass Appropriate for the Hungarian School Curriculum?" Hungarian Cultural Studies. e-Journal of the American Hungarian Educators Association, Volume 7 (2014): http://ahea.pitt.edu

DOI:10.5195/ahea.2014.140

among the Hungarian extreme right wing. Although she claimed that what she wrote in her novel was based on actual facts and events, and though she apparently convinced many readers, her claims are unbelievable. For example, she could not possibly have been present in scenes where private conversations between politicians are quoted verbatim (Kádár 2003), and despite the dramatic progression of events in the volume, the views of the author remain unaltered by her "experiences" of these events. Nonetheless, the novel is well-composed and definitely Tormay's best work. The power of the text is shown not only by the fact that reprints of Bujdosó könyv are selling out rapidly in Hungary, but also by the way certain phrases and conclusions of her novel keep emerging in current extreme right wing political forums and in the rhetoric of right wing politicians. Many of these persons have internalized and quote the interwar right wing's opinions on Mihály Károlyi, Béla Kun, Tibor Samuely and others as expressed in Tormay's book without any reference to her as the source.

\section{József Nyirő (1889-1953)}

Nyirő began his career as a Catholic religious educator and priest, but he abandoned priesthood in order to marry, and subsequently became a journalist who played a prominent role in the cultural life of Transylvania. He was the chief editor of the journal Pásztortüz ['Shepherd's Fire'] published in Cluj-Napoca [Kolozsvár] and was one of the founding members of the Transylvanian Guild of Fine Arts, which published literature and organized meetings and gatherings for artists. As such, Nyirö's short stories and novels were well received in Transylvania and Hungary, where his fans referred to him as the erdélyi próféta ['Transylvanian Prophet'] and, just like Cécile Tormay, in 1940 he also received the Corvin Chain award.

As a journalist, Nyirő became more and more active in politics as a Transylvanian representative, especially after the Second Vienna Decision signed on August 30, 1940 by the representatives of Germany, Italy, Hungary, and Romania to resolve territorial disputes. The decision resulted in the re-annexation of Northern Transylvania to Hungary, which meant that the size of Hungarian territory increased by approximately forty-three thousand square kilometers and its population increased by two and a half million. Due to the reintegration of Northern Transylvania, Nyirö became a member of the Hungarian Parliament, where he openly sympathized with national socialist views (Hegedüs 1991). For instance, on the Nazi-sponsored Day of Poetry held in Weimar in 1941, Nyirö participated as the sole representative of Hungarian writers and gave an enthusiastic interview to the German newsreel in which he praised Europe's "purification by blood and intellectual rebirth," a process that Nyirö attributed to Adolph Hitler.

By the end of 1944, the situation of Hungary had changed drastically. On October 15, Governor Miklós Horthy attempted to leave the side of the Axis Powers but without success. As a consequence, on October 16 Horthy was forced to appoint the leader of the Hungarist Movement, Ferenc Szálasi, as the head of the Hungarian government, and then to resign. After Szálasi's rise to power, the majority of Hungarian parliamentary representatives refused to cooperative with the Hungarists, (or the Arrow Cross as they were generally referred to on account of their logo that resembled the Nazi Swastika), which left only fifty-five members out of three-hundred and twenty-seven to participate in legislative matters. As a result, the Hungarian extreme right wing and the Volksbund representing Hungarian ethnic Germans who sympathized with National Socialism dissolved the Hungarian Parliament and established the National Association of Legislators, which basically functioned as an Arrow Cross Parliament. 
Huszár, Ágnes. "Nationalism and Hungarian Education Policy: Are the Literary Works of Cécile Tormay, József Nyirö, and Albert Wass Appropriate for the Hungarian School Curriculum?" Hungarian Cultural Studies. e-Journal of the American Hungarian Educators Association, Volume 7 (2014): http://ahea.pitt.edu

DOI:10.5195/ahea.2014.140

Nyirö became one of the members of the new parliament and of the Szálasi government, which operated in Budapest until December 1944, when it moved to western Hungary to escape from the imminent occupation of Budapest by Soviet troops and finally sought refuge in Germany. Nyirö was part of the German political emigration as a member of the so-called menekült kormány ['refugee government'] and continued to act as their Minister of National Education. Despite his exile, he remained one of the most loyal followers of Szálasi, even after the latter was captured by American soldiers, brought to court in Budapest, and sentenced to death for war crimes in March 1946. In 1947, Hungarian Minister of the Interior László Rajk requested Nyirő's extradition from German authorities so he could face trial in Hungary, but Germany denied the request as Nyirő's involvement in war crimes was unproven. Afterwards, Nyirő moved from Germany to Madrid and lived there until his death in 1953.

József Nyirö became well-known as a writer for his atmospheric and rhetorically creative short stories that were later compiled into two volumes, Jézusfaragó ember ['The Man Who Carved Jesus'] (1924) and Kopjafák ['Grave Markers'] (1933), as well as his historical novels such as A sibói bölény ['The Buffalo of Sibó'] (1926-1929), Madéfalvi veszedelem ['The Peril of Madéfalu'] (1939) and Néma küzdelem ['Silent Struggle'] (1944). His short stories all revolve around the everyday life of Szeklers and their heroic struggle with nature and against their oppressors such as Austrians, aristocrats, clever and conniving lawyers and tax collectors. These short stories usually end on a tragic note where the protagonists are either driven to insanity or death, as suggested by the title Kopjafák. However, impressive as these short stories may be, they do suffer from Nyirö's greatest shortcoming as a writer: his inability to edit and chisel his work to root out fragments and superfluous segments from the final version of his texts. For instance, the short story A karácsony bolondja ['The Fool of Christmas'] begins with a powerful opening where an old retired theatrical performer called Tiborc plants his entire backyard with pine trees to await the return of his dead infant son, but the short story ends in a sentimental onslaught. The protagonist asks the priest to borrow the infant Jesus figure from the nativity scene, pretends it plays with his imagined child, and then puts them both into bed. The author then has the priest, as narrator, who watches the unfolding scene with tears in his eyes, relate how the protagonist "muttered under the breath" a dreary, didactic recital of the Sermon on the Mountain.

Nyirö's literary works show a high level of disorganization on the structural level as well as in their language use, rife with attempts at expressive rhetorical imagery, dialect phrases and single-use words or hapax legomena. Such rhetorical elements occasionally give a boost to Nyirö's sentences, but in the majority of instances they have an unintentionally comical effect. For instance, the following excerpt is meant to express the arrival of night fall:

The night has not yet awoken, but already the stars have scattered every which way and the cries of the birds whipped the sky. The foxes' bosoms bore sleeping sons, but heavenly fire had cleansed the womb of the animals and the God holding vigil above them sat on his bed too to snooze a tad (Nyirő 1995: 153).

[Még nem egészen felébredve az éj, de már a csillagok széjjelbolyongottak, s a madarak szavokkal az eget verték. A rókák kebelén aludtak a fiak, de az égi tüz 
Huszár, Ágnes. "Nationalism and Hungarian Education Policy: Are the Literary Works of Cécile Tormay, József Nyirö, and Albert Wass Appropriate for the Hungarian School Curriculum?" Hungarian Cultural Studies. e-Journal of the American Hungarian Educators Association, Volume 7 (2014): http://ahea.pitt.edu

DOI:10.5195/ahea.2014.140

már megtisztította az állatok méhét s a felettük virrasztó Isten is leült ágyára, hogy egy cseppet szunditson.]

Nyirő's shortcomings as an editor are especially apparent in his novels, including his best-known historical novel Madéfalvi veszedelem, which is based on events from 1764 when Habsburg ruler Maria Theresa wanted to establish a Szekler regiment but the Szeklers resisted claiming their ancient privileges. As a consequence, four hundred people were killed in a raid by the Habsburg forces, including women and children. The novel is a loosely structured series of humorous and dramatic episodes that fail to form a coherent whole due to Nyirö's inability to plot out an entire novel-length composition (Béládi 1966: 176). The protagonist of the novel is the Szekler community with a few prominent characters such as the priest Péter Zöld and resistance leader István Lázár, who come face to face with the murdering and pillaging Habsburg army supported by the local Saxons and led by the diabolic General Buccow. The clash of good and evil forces culminates in a horrific description of the bloodshed with frozen corpses and blood spilled on the virgin snow, and though the text suffers for its structural deficiencies, the majority of its scenes are expressive and potent.

Similarly to Madéfalvi veszedelem, Nyirő's 1940 novel Halhatatlan élet ['Immortal Life'] also centers around the struggle of good Szeklers against their demonically evil adversaries, who in the case of Halhatatlan élet are represented by a Jewish outsider. The plot takes place before World War I and its first person protagonist is a young Szekler man who struggles with nature to support his family and receives support from the inhabitants of his village, who are all smooth-talking but soft-hearted Szeklers. The only "outsider" in the village is a Jewish innkeeper and banker called Izsák, who sells bad wine at high prices and good wine for a fortune. In the novel, Izsák makes a curious offer to the protagonist and asks to buy the financial fine the young man was charged with for illegal woodcutting. The banker only asks for a portion of the actual price and tells the young man that he would supply or bargain for the rest. When the young man and his father accept his offer, "Izsák smiled and retreated into the night where he belonged" [Izsák úr pedig mosolygott és visszavonult az éccakába, ahonnan való] (Nyirö 2009: 180). The reader then discovers that Iszák tricked and robbed the young man's family, as all fines had been dropped in honor of the newly implemented constitution.

Nyirö's worldview is perhaps most prominent in his last and longest novel Néma küzdelem, a historical novel published in 1944 that takes place in the age of dualism, and whose title refers to the struggle for retaining the Hungarian identity of Transylvanian villages in the face of Romanian oppressors. In the semantic fields of the novel, Hungarians and Romanians appear in complementary distribution as stark opposites, with the Hungarian characters retaining some semblance of value even at their lowest points while the Romanian characters are only ever presented in a negative light, even in less prominent parts of the text. For example, one of the characters, an old Hungarian count, goes on an outing into the countryside and observes the following: "The weather is especially lovely, not a single cloud in the sky. The Vlachs are plowing the fields superficially, sinfully, ruining the precious soil" [Az idö különben szép, az égen egyetlen felhö sincs. A mezökön oláhok szántanak felszínesen, vétkesen, elgazolva a drága földet] (406). In another scene, Nyirö presents the changes in the identity of the local population, the continuous erosion of the Hungarian language and the people's gradual integration into Romanian society as a terrible catastrophe: 
Under the constant cankerous pressure, this once proud, rebellious, haughty, magnanimous, enduring, seemingly indestructible, keen-sighted and tough people has sunken to the level of its unworthy, inferior environment. It's easier to live in shame and no standards, in the stench of filthy rags, simplistically, on the level of animalistic desires, completely letting themselves go, once they can sink low enough to lose their humanity (Nyirő 2004: 356).

[Az egykor büszke, lázadó, gögös, nagylelkü, szivós, elpusztithatatlannak látszó, fölényes látású, kemény nép a folyton sorvasztó súly alatt hozzázüllik a méltatlan, alsóbbrendü környezethez. Abban könnyebb élni, szégyen, igények nélkül, a rongy büzében, kezdetlegesen, az állati vágyak szintjén, megfeledkezve önmagukról, ha valaki annyira le tud süllyedni, hogy elveszítse ember voltát.]

The antagonistic portrayal of Romanians in the silent struggle for Hungarians for land and the preservation of Hungarian identity is blatantly obvious in Nyirö's novel, but in the afterword of the 2004 reprinted edition, Béla Pomogáts evaluates the author's intent as follows:

[Nyirö] stood guard over the everyday struggles of the decimated Hungarian population with intimacy and empathy in order to at least serve as their annalist and record the collective morals and history of these self-defending, selfpreserving and thereby nation-preserving struggles (Pomogáts 2004: 420).

[[Nyirö] bensőséges empátiával hajolt a fogyatkozó magyarság mindennapi eröfeszitései fölé, hogy legalább krónikásként megörökitse ezeknek az önvédö, önmegtartó-és ezzel nemzetmegtartó-eröfeszitéseknek a közösségi morálját és történetét.]

In his novel Néma küzdelem, Nyirö presents the territorial losses of Transylvanian Hungarians to settling Romanians and their opposition to the resident Jewish population as a "struggle of ethnicities" or, in his own words, the "war of the races," and is openly anti-Semitic in his rhetoric not only in Néma küzdelem but other works as well. For instance, Nyirö tended to emphasize the supremacy of Hungarians by presenting non-Hungarian characters as animalistic subhuman creatures, demonic evil forces, or both. One of the most striking examples of anti-Semitism in Néma küzdelem is a passage in which one of Nyirö's most sympathetically portrayed characters, Jóska Vincze Kiss, makes an observation about a Jewish couple that suggests the author had extensive knowledge of the operation of concentration camps. Considering that the novel was published in 1944 and Nyirö was an avid supporter of Goebbels and Hitler, he must have heard of their methods of "recycling" dead bodies such as making soap from human corpses, which is hinted at in his character's scornful remarks on the wife of a Jewish shopkeeper:

This Zweig is a decent man. He listens to reason. He cannot bear to see how these poor unfortunate women are so flat and dry as a board, while his wife's belly, not to mention the other half, is as big as a globe. If she were to wring her hair, she'd 
Huszár, Ágnes. "Nationalism and Hungarian Education Policy: Are the Literary Works of Cécile Tormay, József Nyirö, and Albert Wass Appropriate for the Hungarian School Curriculum?" Hungarian Cultural Studies. e-Journal of the American Hungarian Educators Association, Volume 7 (2014): http://ahea.pitt.edu

DOI:10.5195/ahea.2014.140

be dripping fat... Though it is true that not every woman is good soap material...(Nyirö 2004, 361).

[Tisztességes ember ez a Zweig úr. Megérti az okos szót. Nem nézheti, hogy ezek a szerencsétlen fehérnépek olyan laposak, szárazak, mint a decka, s az ö

feleségének akkora hasa van, hogy a másik részét ne is emlitsem, mint a födgömb. Ha a haját megcsavarja, abból is zsír csepeg ki... Az is igaz, hogy minden asszony nem lehet szappannak való...]

\section{Albert Wass (1908-1998)}

Albert Wass had an intriguing career, but due to his contradictory statements and questionable biographical sources, little is known of the author whose autobiographical texts show great fluctuation in terms of facts and periods of his life. Nevertheless, we know for certain that he hails from an ancient family of Transylvanian nobles who received the title and rank of Count in 1764 from Habsburg ruler Maria Theresa, and played an important role in the public sphere of Transylvania as soldiers, diplomats, and members of the clergy. Albert Wass was raised in a noble milieu and upon his graduation from the Calvinist High School in Cluj-Napoca [Kolozsvár], he continued his studies in the field of agriculture in Debrecen, Hohenheim, and at the Sorbonne. After his return to Transylvania, he lived the life of a wealthy noble who not only loved to hunt and manage his large estate, but also had great ambitions in the field of literature. His poems, short stories, and novels were met with great appreciation by the public. Wass joined the Hungarian army in 1943, and in 1944 fled from Hungary to Gemany with the defeated army. He emigrated to the United States in 1952 where he lived until his death in 1998. He was unable to return home, partly due to criminal charges raised against him by the Romanian government. In 1946, the People's Court of Romania issued a decision that Wass and his father were guilty of instigating the murder of four people on their estate in 1940. Since two of the victims were Jewish women, the Wiesenthal Foundation was also involved in the investigation, but when the Romanian government sent a request to the United States Ministry of Justice in 1979 for the extradition of Wass, the Ministry denied the request due to insufficient charges. Wass himself stated that the charges were false and claimed he had saved eighteen Jewish families from the German troops, but no evidence has been found to support his claim.

In the second half of his life, Albert Wass lived in the United States and spent most of his time in the state of Florida, where he continued to write Hungarian-language literature and engaged in politics on behalf of the Hungarian population of Transylvania. He founded publishing houses, organized meetings and attempted to influence the US senate on the issue of Transylvanian Hungarians since, according to his letters, one of his goals was to organize the collective international political presence of Hungarian emigration (Turcsány 2008). Wass always considered his stay in the States to be temporary, but claimed he could not return to Transylvania because the Romanian Secret Services was constantly tracking him to assassinate him. Once he was hit by a car, which he claimed was not an accident but an assassination attempt by the Romanian Securitate. After the fall of the Socialist system in Hungary, Wass hoped to become a Hungarian citizen and sought the support of his friends, who managed to convince the Hungarian authorities to award him one of the highest orders of merit, the Civilian Commander 
Huszár, Ágnes. "Nationalism and Hungarian Education Policy: Are the Literary Works of Cécile Tormay, József Nyirö, and Albert Wass Appropriate for the Hungarian School Curriculum?" Hungarian Cultural Studies. e-Journal of the American Hungarian Educators Association, Volume 7 (2014): http://ahea.pitt.edu

DOI:10.5195/ahea.2014.140

Cross of the Republic of Hungary in 1993, and in 1997 the Hungarian Ministry of the Interior also approved his request for Hungarian citizenship. However, Wass never managed to return to Hungary, as his children in the U.S. disapproved of his last marriage and his final years were spent in bitter familial disputes. This led to his committing suicide with his own hunting rifle in 1998. Upon his death, some of his fans suggested that in fact Wass was assassinated by agents of the Securitate, but no evidence has been found to support these claims.

Unlike Cécile Tormay and József Nyirö, Albert Wass is presently a popular author in Hungary and has a wide and enthusiastic readership. His books have been in print since 1990 and there are publishers, Kráter in particular, that have dedicated themselves to publishing Wass' novels, short stories, poems and any and all writing pertaining to Wass or his literary works. Wass' popularity is also evidenced by monuments dedicated to him and by the growing number of streets, libraries, and cultural institutions named after him. Perhaps the most telling fact is that one of his novels, A funtineli boszorkány ['The Witch of Funtinel'] was voted one of the twelve most popular novels in the Hungarian Big Read contest of 2005, with two of his other novels making the top fifty list.

During his long life, Albert Wass wrote many poems, short stories, novels, and children's books that were almost exclusively about the present and past of Transylvania and the fate of Transylvanian Hungarians, and were therefore considered a continuation of the Transylvanian literary tradition. In his early years, he was warmly welcomed in Transylvanian and Hungarian literary circles as a noble aristocrat and a talented representative of the Transylvanian Guild of Fine Arts, and as such he received positive reviews from journals as well as literary awards. Given that his most important mission was the preservation of Transylvanian Hungarian identity, he did not stop writing about the same themes that made him well-known even after he had to leave his homeland and was faced with the reality of not being able to return in the discernible future. His literary works were basically a call for attention to the political oppression of Transylvanian Hungarians, as shown by the fact that he dedicated the English version of his novel Adjátok vissza a hegyeimet ['Give Back My Mountains to Me'] to Eleonor Roosevelt, founder and president of the Human Rights Association (Turcsány 2008).

Albert Wass' literary works are popular in today's Hungary due to several factors such as Hungarian readers' nostalgia for the romanticized landscapes and relics of Transylvania and its illustrious historical persons and events. His work is also popular because, under the Hungarian Socialist dictatorship, the works of émigré writers were withdrawn from public libraries and very few Transylvanian writers were allowed into the official Hungarian literary canon. Only a few select writers such as Áron Tamási and Lajos Áprily were admitted, while the works of members of the Transylvanian Guild of Fine Arts, including Albert Wass, were only available in earlier editions. One of the most prominent examples of authors whose works were not featured was Sándor Márai, who was silenced in the 1950s and 1960s and who was finally acknowledged as a significant writer by official Hungarian literary historians in the 1980s. However, due to the presence of Soviet troops in Hungary, Márai did not allow his works to be reprinted until the 1990s, which meant that similarly absent authors such as Wass were enticing to readers as formerly taboo fruit. However, their situation does not explain why their fellow Transylvaniaoriented authors are barely known in Hungary, including aristocrat Miklós Bánffy (1873-1950), who was not only an intriguing character of great personal integrity, but also a writer of greater 
Huszár, Ágnes. "Nationalism and Hungarian Education Policy: Are the Literary Works of Cécile Tormay, József Nyirö, and Albert Wass Appropriate for the Hungarian School Curriculum?" Hungarian Cultural Studies. e-Journal of the American Hungarian Educators Association, Volume 7 (2014): http://ahea.pitt.edu

DOI:10.5195/ahea.2014.140

aesthetic merit than his more well-known peers, as evidenced by his notable success among German readers.

Although the above mentioned reasons for Albert Wass' popularity hold true for József Nyirö as well, there is a great difference (one that goes in Wass' favor) between the two authors in terms of popularity. His simple structures, linear plots, and clear-cut distinctions between good and evil characters make his literary works far more palatable for Hungarian readers than those of Nyirö. In Wass's Transylvanian universe, evil is represented by the Romanians, or "Vlachs," and the Jews, while good is represented by the pure, loyal but ignorant and gullible Hungarians and the nobles who educate, raise, and govern them as intellectuals, father figures, and educators. Those on the side of good stand by their "god given" traditional values that the evil side wants to destroy, and oppress those who wish to destroy the Hungarians, namely the Romanians and Jews who often join forces with external enemies, the pro-Nazi Germans and the Communist Russian or Soviet troops.

An examination of the dualistic view of good and evil in Wass's novels is his $A z$ antikrisztus és a pásztorok ['The Antichrist and the Shepherds'], in which the son of a Jewish shopkeeper returns to his Transylvanian village as the leader of Communist terrorists. Tragedy is averted only through the self-sacrifice of a Hungarian notary of noble birth. However, there is also salvation for the Jewish intellectual referred to as the "Antichrist" once he loses his faith in the demonically evil Soviets and opposes them. He then finds true love in the form of a simple, ignorant, but deeply insightful girl from his homeland. When we consider the plot of the novel in its purest essence, it seems less like a realistic narrative of events and more like a tale bordering on surreal myth; it is as though it had gone through so many folk storytellers that it turned into a mystical folk legend. A funtineli boszorkány is similar in its use of mythical elements, as the protagonist, the beautiful Transylvanian girl Nuca, is the embodiment of unstoppable natural forces. All men who become involved with her end up dead. However, the girl herself turns to God and becomes more deeply religious as the plot unfolds, until she practically achieves sainthood by the end of the novel. The transition is successful due to carefully increased suspense and a good balance achieved between the hints of the untamed sexuality of the girl and the certainty of her religious conversion. This is why A funtineli boszorkány is considered one of the more aesthetically valuable works of Wass.

One of Wass' most characteristic literary works is his novel Kard és kasza ['Sword and Scythe']. Encompassing almost a millennium of Transylvanian history through the history of an ancient noble Transylvanian family reminiscent of Wass' ancestors, the novel also features his most prominent rhetorical tropes. Most of the novel concerns the heroic struggle of the author's alter ego, Count Miklós, to preserve Hungarian historical, moral, and economic traditions in the face of both internal and external enemies, including the vile Germans and the barbaric Communist Soviets. However, the greatest enemies in the novel are the Romanian characters, who appear merely lazy or corrupt in times of peace but reach diabolical heights upon the Soviet occupation, as shown by the utmost cruelty of their capturing one of the counts and flaying him alive. Similarly, the Jewish characters are also treated as the essence of depravity and ingratitude after all the help they had received from the Hungarian characters. In contrast, morally upright Count Miklós loses his estates, money, privileges and even his eyesight by the end of the novel, but in his fall, he is elevated as a veritable saint, a blind prophet whose only remaining company is the former servant of the noble family. This relationship, the symbiotic coexistence of these 
Huszár, Ágnes. "Nationalism and Hungarian Education Policy: Are the Literary Works of Cécile Tormay, József Nyirö, and Albert Wass Appropriate for the Hungarian School Curriculum?" Hungarian Cultural Studies. e-Journal of the American Hungarian Educators Association, Volume 7 (2014): http://ahea.pitt.edu

DOI:10.5195/ahea.2014.140

two different social groups, is what inspired the title Kard és kasza and is represented by Wass in the novel as the only viable alternative for a solid future.

Despite Wass' popularity and scholarly attempts to present his literary works as high literature through analyses that suggest the presence of a folkloristic prosaic rhythm in his writing (A. Jászó 2002-2003), the general consensus in Hungarian literary studies holds that the structural shortcomings of Wass' writing, as well as their monotonous and simplistic rhetoric, are on the level of popular literature. For example, Lajos Grendel argues in his detailed volume on twentieth century Hungarian literature that Albert Wass is a writer of popular fiction rather than an artistic one (Grendel 2010: 313).

\section{Conclusion}

Although Hungarian education policy has in all political periods been influenced by the dominant ideology of the current regime, it is perhaps unprecedented that political parties actually succeeded in their demands to integrate the works of nationalist authors such as Tormay, Nyirö, and Wass into the Hungarian literary canon.

Having considered the life histories of Cécile Tormay, József Nyirő and Albert Wass in the light of contemporary and current Hungarian politics, we may well ask whether their literary works are suitable as school literature for children. A careful literary analysis of these works shows that they are unsuitable for children based on their aesthetic value and articulated worldviews. These three authors represent an authoritarian view that divides groups of people into good and evil, and several of their works, including Nyirö's Néma küzdelem, Tormay's Bujdosó könyv and A régi ház, and several of Wass' novels can inspire xenophobic attitudes towards other nations and ethnicities. Moreover, the rhetoric of all three authors features the opposition of the Hungarian race against other races. While this may be presented in the general Hungarian sense of "historically established cultural nation" rather than as a propagation of Nazi racial theories, it is still problematic and misleading. To expose children to such rhetoric as compulsory school literature is problematic and deeply troubling.

The decision of whether the life work or a portion of the works of Tormay, Nyirö and Wass may be integrated into the Hungarian literary canon falls within the scope of Hungarian literary studies, but the three authors in question have received little critical and professional scholarly attention. The majority of studies are either apologetic or unprofessional (Pirint 2006, Turcsányi 2008). This itself is a product of prevalent trends in Hungarian literary studies where scholars only devote attention to literary works that are considered aesthetically valuable by widespread scholarly consensus. Such literary studies either spare no time for the thoughtful analysis of popular literature and second-rate or third-rate literature, or analyze such literature from a sociological rather than a literary perspective. Due to the lack of critical analyses of popular works, these might be integrated into Hungarian youth literature then trickle down to Hungarian literary education, which operates with the assumption that only high quality literary texts are integrated into the school curriculum and therefore any critical or analytical reading of these texts is unnecessary and their authors are suitable to present to school children as role models. Such views also conform to the general view of Hungarian public education, that the role of schools is to instill the knowledge of unquestionable truths rather than foster the development of an independent and critical perspective. 
Huszár, Ágnes. "Nationalism and Hungarian Education Policy: Are the Literary Works of Cécile Tormay, József Nyirö, and Albert Wass Appropriate for the Hungarian School Curriculum?" Hungarian Cultural Studies. e-Journal of the American Hungarian Educators Association, Volume 7 (2014): http://ahea.pitt.edu

DOI:10.5195/ahea.2014.140

When we examine the validity of the Hungarian education policy decision to incorporate the works of Cécile Tormay, József Nyirö, and Albert Wass into the school curriculum, it is important to consider the pedagogical aspects of texts that are deemed suitable to be children's literature. Aesthetical value should be considered a primary factor in the selection of literary works for school reading, especially since the pool of works belonging to the Hungarian literary canon and works suitable for children do not automatically overlap. First and foremost, children's literature includes texts that not only help children master reading and reading comprehension, but also meet certain developmental and psychological criteria. For instance, it is important that children be able to immerse themselves in the plot of the text and identify with the characters, since such texts can also be therapeutic for children and adolescents in facing and overcoming their fears and frustrations. Also, the reading strategies of children have to be accommodated in the process, and these strategies generally involve the immediate and naive reception of texts, or as István Kamarás puts it, "[children] tend to dissolve in the fantasy world of texts rather than the other way round" [nem annyira bennük oldódik fel a mü, mint ök a mü álomvilágában] (Kamarás 2007: 149).

Having taken pedagogical and developmental psychological aspects into consideration with regard to the question of whether Tormay, Nyirö, and Wass are suitable as children's literature, I would conclude that the works of these three authors are unsuitable as children's literature and compulsory school literature. While these works serve the interests of current Hungarian education policy in fostering a sense of nationalism in children as well as a close relationship to Hungarian language and culture, they do so at the cost of inciting xenophobia and hatred towards other nations and ethnic groups. Their themes are also largely irrelevant to the lives of Hungarian youth today and their texts offer little opportunity for immersion and identification. Finally, the aesthetic value of the works under discussion is negligible as well, which means that these texts are not even suitable to communicate aesthetic and moral values to children and help them become sensitive and critical readers.

\section{Works Cited}

A. Jászó, Anna. 2002-2003. "Wass Albert prózai müveinek stílusa” ['The Prose Style of Albert Wass']. Polísz, 68 (2002-2003): 55-72.

Béládi, Miklós. 1966. Konzervatív irodalom. A magyar irodalom története 6 kötetben ['Conservative Literature: The History of Hungarian Literature in Six Volumes']. Budapest: Akadémiai Kiadó, vol. 6: 160-178.

Borgos, Anna. 2011. "Sándor/Sarolta Vay, a Gender Bender in Fin-the-Siècle Hungary." In Comparative Hungarian Cultural Studies. Eds., Steven Tötösy de Zepetek and Louise O. Vasvári. West Lafayette, Indiana: Purdue University Press, 220-231.

Gombár, Zsófia. 2009. “Az 1978-as reformtanterv szerepe a magyar irodalomtanítás történetében" ['The Role of the 1978 Reformed School Curriculum in the History of Hungarian Literary Education']. http://www.tanszertar.hu/eken/2009_01/gzs_0901.htm

Grendel, Lajos 2010. A modern magyar irodalom története. Magyar líra és epika a 20. században ['The History of Modern Hungarian Literature: Hungarian Poetry and Narrative Poetry in the Twentieth Century']. Pozsony: Kaligram. 
Hegedüs, Géza. 1991. "A magyar irodalom arcképcsarnoka" ['The Portrait Gallery of Hungarian Literature']. http://www.mek.oszk.hu/01100/01149/html/nyiro.htm

Jankovics, József. 1986. "Hungarian Quasi Family Novels of the Seventies." Neohelicon, 23 (1986): 195-205.

Kádár, Judit. 2003. "Az antiszemitizmus jutalma. Tormay Cécile és a Horthy-korszak"

['Rewarding Anti-Semitism: Cécile Tormay and the Horthy Era']. Kritika, 3 (2003): 9-12.

Kamarás, István. 2007. Az irodalmi mü befogadása ['The Reception of Literary Works']. Budapest: Gondolat.

MTI. 2012. “Takaró Mihály: elfogulatlanul és teljes körüen kell bemutatni a XX. század magyar irodalmát" ['Mihály Takaró: For an Unbiased and Comprehensive Presentation of Twentieth Century Hungarian Literature']. http://tortenelemportal.hu/2012/02/takaro-mihaly-teljeskoruen-kell-bemutatni-magyar-irodalmat/

Nyirő, József. 1995. Havasi tragédia ['Tragedy in the Mountains']. Budapest: Aqua.

—. 2004. Néma küzdelem ['Silent Struggle']. Csíkszereda: Pallas-Akadémia.

- Halhatatlan élet ['Immortal Life']. Szeged: Lazi.

Orosz, Ildikó. 2013. “'Nem lehet a Himalájával kezdeni'—Fenyő D. György magyartanár” ['We Can't Start with the Himalaya'-Hungarian Literature Teacher D. György Fenyő].

http://magyarnarancs.hu/konyv/nem-lehet-a-himalajaval-kezdeni-87630

Pomogáts, Béla. 2004. "Utószó" ['Postscript']. In József Nyirő, Néma küzdelem ['Silent Struggle']. Csíkszereda: Pallas-Akadémia, 419-430.

Pirint, Andrea. 2006. "A régi ház mint kortörténeti dokumentum. Adalék Tormay Cécile életmüvének újrafelfedezéséhez" ['The Old House as a Contemporary Historical Document: Supplements to the Rediscovery of Cécile Tormay's Life Work']. http://www.jamk.hu/ujforras/0709_12.htm

Tormay, Cécile. n. d. A régi ház ['The Old House']. Budapest: Kvalitás Duó.

— 1923. Bujdosó könyv. Feljegyzések 1918-1919-böl ['Hiding Books: Diary Entries from 1918-1919']. Third edition, volumes 1-2. Budapest: Pallas.

Turcsány, Péter. 2008. Wass Albert, a boldog szomorúember [“Albert Wass, a Happy Sad Man']. Pomáz: Kráter. 